\title{
Why not reform the United Nations?
}

The low-key celebrations of the half-century of the United Nations has served chiefly as a reminder that the organization is ripe for reform - but not abolition.

THE United Nations celebrated its fiftieth anniversary last weekend with modesty that was all too appropriate, but nevertheless a disappointment. The UN Charter is the product of negotiations carried out between the major powers when the Second World War still had many battles to run. That so many could have been so optimistic that the problems ahead of them would prove tractable is an exhilarating proof that hope can sometimes triumph over despair. The disappointment in last week's proceedings is that the United Nations should now be as dispirited as appears to be the case, and just when it seemed that it was coming into its own. Whatever happened to the "new world order" President George Bush was talking of just a few years ago?

Part of the truth is that organizations like the United Nations can expect to be popular among their constituents only sporadically, when by accident they have managed to please everybody. For most of the time, they must expect a majority of malcontents among their members. (The European Union is learning as much the hard way.) The United Nations also suffers from perennial budget problems, which are dispiriting and are inevitably worsened by present efforts to keep peacekeepers in a dozen potential (and actual) battlefields. Dr Boutros Boutros Ghali, the director-general, is right to complain that it makes no sense for the Security Council to will a peacekeeping force here or there when its members will not meet the cost. The United Nations is not to blame for all its own ills.

Yet the present clamour for reform (especially in the United States) cannot be dismissed as unavoidable discontent. Indeed, it is no surprise that an organization able just to hold itself together when the Cold War severely limited its capacity to act is found wanting now that circumstances have given it a wider canvas. The most obvious present difficulty is the diversity of the functions member states expect of the United Nations. At one end of the spectrum is the general obligation to assist the development of developing countries; at the height of the Cold War, there was nothing much else to do. At the other are military and quasi-military activities. (The Korean and Gulf Wars are in the first category, the intervention in Bosnia in the second.) In between are the activities of the specialized agencies (the World Health Organization, WHO, for example) and the diplomatic task of negotiating international treaties.

How to make that mess manageable? An obvious need is to give the specialized agencies more autonomy and more responsibility. Their management now falls awkwardly between the United Nations in New York and their own general assemblies, in which civil servants are the chief participants. Their heads are appointed on political grounds ("Who's turn is next?"); if they play their cards shrewdly, they can do a poor job and still be elected for a second term - WHO is the latest illustration of that principle. The bureaucracy generally has the whip-hand over the meritocracy. The best solution is that the directors of these organizations, who must be in charge of their own affairs from day to day, should be responsible to a body of identifiable trustees in general, and to the corps of international civil servants month by month. That way, there would be more action and less spending.

At the other extreme, similar expedients would make sense. Boutros Boutros Ghali is not qualified as a general, but has lately been functioning as a kind of commander-inchief. He has military advisers, but they come and go and tend to be superannuated. It may at this stage be too much to ask that the United Nations should recruit military forces of its own, but there is a case for a peacekeeping staff college and for a small hard core of military people on the staff. $\square$

\section{Clinton two strikes down}

The US president has lost his nomination for surgeongeneral and made a mess of an immunization programme.

THAT hardly anything, these days, goes right for President Bill Clinton is no surprise: both houses of the US Congress are dominated by his political opponents. Thus the Senate's failure last week to approve the nomination of Dr Henry W. Foster as surgeon-general, but to leave it (and him) in indefinite suspense, was predictable. The decisions not to end debate on the question, but also not to bring the issue to a vote, offers the president a distasteful choice: either nominate somebody else or make do without a surgeon-general.

The president is right to complain that the Senate's actions were politically motivated, but politics are rarely distant from nominations procedures. On this occasion, the Republican leader in the Senate, Mr Robert Dole, who is at present the leading opposition candidate for Clinton's own job in the 1996 election, made three telling points. He demonstrated to Clinton the power of the new Senate, he bested one of his declared rivals for the presidency (Senator Phil Gramm) by showing that he could scupper the nomina- 